\title{
Tourism Education in Azerbaijan: Current Situation, Problems and Solutions
}

\author{
Gadir Bayramli ${ }^{1}$, Teymur Sarkhanov ${ }^{2}$ \\ ${ }^{1}$ Azerbaijan State University of Economics (UNEC) Baku, Azerbaijan. E-mail: kadirbayramli@gmail.com \\ ${ }^{2}$ Azerbaijan State University of Economics (UNEC), Baku, Azerbaijan. Sakarya University Graduate School of \\ Business, Turkey. E-mail: teymur.sarkhanov@gmail.com. ORCID: 0000-0002-2022-9342
}

Article History: Received: 10 November 2020; Revised 12 January 2021; Accepted: 27 January 2021; Published online: 5 April 2021

\begin{abstract}
Tourism has been chosen as one of the priority areas among non-oil sectors. Although there are prerequisites for the development of tourism in a country with rich natural and historical-cultural recreation resources, the use of the country's rich tourism potential is not sufficient. One of the reasons why tourism cannot achieve any result is the problems of tourism education. This problem is also delaying the transition to the sustainable development of tourism. These reasons make it necessary to carry out research on tourism education, identify and solve problems. Some issues related to tourism education have been touched upon in the Strategic Roadmap for Tourism Development, tourism-related programs, and some tourism textbooks, and highlighted the importance of solving the problem. Almost all tourism education institutions and most of the qualified cadres in tourism are concentrated in the capital Baku and other major cities. This indicates that there is an inequality in the location of skilled cadres in the field of tourism, and according to these figures, the regions are far behind the major cities like Baku, Ganja, and Sumgait. Investigation of tourism education requires comprehensive and systematic analysis. Statistical analysis, comparative analysis, and SWOT analysis methods have been used in this article, which examines the problems of tourism education in Azerbaijan. If problems on tourism education are solved, it will be possible to make better use of the country's recreational potential and improve the quality of tourism services. The problem of tourism education is to increase the number of enterprises providing tourist education, to study and apply the experience of developed countries, to strengthen the staff in the tourism education institutions, to introduce innovative methods of teaching, to improve the quality of textbooks, to enhance tourism education in the regions, and to provide internship opportunities for students and young researchers to meet their needs.
\end{abstract}

Keywords: Tourism education, innovative methods, effective use, staff, internship opportunities.

\section{Introduction}

Tourism has a special place in the non-oil sector is developing fast during the last few years. Infrastructure in the tourism destinations is strengthening and the number of foreign tourists is increasing. All this requires increasing the number and quality of specialized personnel for the tourism sector. And strengthening the cadre is possible by tourism education meeting the modern requirements. Despite not any special program of tourism education was prepared in Azerbaijan, tourism education was shown as one of the priorities in the Strategic Roadmap and other State Programs, and increasing of investment in this field was overseen. There is a need for a detailed investigation of tourism education for the development of this sector.

Because of a small number of statistical data on tourism education and broadcasting on the topic, the preference has been given to information from the Internet. This article aims to partially remedy the deficiency in the field of tourism education in Azerbaijan.

\section{Methods}

The methods of statistical analysis, comparative analysis, and SWOT analysis methods have been used in this article. Because of that, there are not any detailed data on tourism education in Azerbaijan in the reports of the State Statistical Department, State Tourism Agency, and other state bodies, it has been forced to use incoherent information placed on the Internet. When using the comparative analysis method, such countries as Turkey and Russia, having similar economic and social status and peculiarities of development of tourism as well as having 
close tourism relations with Azerbaijan have been chosen. By SWOT analysis the strong and weak sides of tourism education in the country, as well as opportunities and threats, have been pointed out.

\section{Tourism education and its significance}

Tourism education means such activities as imparting tourism consciousness (concept) to students, teach basic principles of hospitality, improve general and professional knowledge of personnel working in the tourism industry, and grow managers, research specialists, and technical workers for this industry. The aims of tourism education are to impart tourism consciousness (concept) to people, to increase productivity in the tourism sector, to give professional knowledge and behavior to personnel rendering service to tourists, to teach future workers to provide balance among authority, capacity, and responsibility (Mavis \& Kozak, 1992).

Tourism education opens up wide opportunities for saving cultural and historical heritage thereby saves not only monuments as material objects but also language, customs, folklore, and many other ethno cultural components. Professional tourism education molds a specialist who is responsible for the holistic and constructive development of the whole tourism movement (Fedulin, 2008). Tourism education is necessary for coping with a strong and dynamic marketing conception, getting support from lobbies for the favor of the country, forming public opinion, establishing public relations, and solving complex problems caused by marketing.

The Professional and qualification structure of the personnel of tourism is permanently improving since dynamic changes of consumer demand and social and economic conditions of tourism business require proper corrections. At the same time, the existing practice of preparation of personnel of a country has to be permanently harmonized with the world practice and standards. For effective production activity, the content of preparation of tourism personnel should be defined by qualification testimonial representing a science-based set of professional abilities and skills officially fixed in qualification requirements at the state level.

Principles of educational conditions and models of the formation of highly skilled specialists - tourism activity leaders at vocational guidance level through the first level of professional education (colleges), tourism type of higher schools, and graduate schools in conditions of Azerbaijan deserve consideration.

Tourism education should be approached not only as preparation of personnel but also as educating investors and leaders, tradesmen, managers of both public and private sectors, and on the whole the people.

\section{Comparative analysis of tourism education in Azerbaijan}

Tourism education is provided in about 10 universities and 2 specialized colleges. Baku State University (BSU) started tourism education in 1980 as the first step. The main scientific direction of the Department of Economic and Social Geography of Foreign Countries and Tourism of the Faculty of Geography of BSU is Development Perspectives and Regional Problems of Tourism in Azerbaijan. The Department has relations with Balikesir University, Chanakkala University, and Turksoy Centre in Ankara (Oliyeva, 2008). This university is the first higher school starting tourism research. At present, the university prepares personnel on Tourism and Hoteling specialization. Some students have internships in foreign countries (USA, Turkey, and Cyprus) during summer.

The only university specialized in Tourism Education in Azerbaijan is Azerbaijan University of Tourism and Management which was established in 2006. 3 faculties and 9 academic departments specialized in different fields of tourism are acting in the university. Students specialized in Tourism and Hoteling have their internships not only in Azerbaijan but in other countries, too. Students can individually apply for this practice and use chances coming from the cooperation of the university with foreign hotel and tourism companies located in Kazakhstan, Germany, Malta, Dagestan, Israel, Greece, Russia, Spain, Turkey, Czech Republic, USA, Northern Cyprus, Ukraine, UAE, and Seychelles Islands. An agreement on a double degree program was signed between Azerbaijan University of Tourism and Management and Krems University of Austria (Bayramli \& Aliyev, 2020). After gaining the independence of Azerbaijan in 1991, tourism sections have been opened in public and private universities and now these sections are acting in about 10 universities.

Tourism sections are acting in the Turkish World of Economics Faculty of the Azerbaijan State University of Economics and its Zaqatala branch having highly qualified specialists and infrastructure for tourism education. Tourism section students have opportunities to have internships in various tourism enterprises. Besides these universities, tourism sections are acting in Azerbaijan Cooperation University, Ganja State University, Mingachevir State University, Lankaran State University, Western Caspian University, and Sumgayit State University. The majority of sections providing tourism education are located in Baku (Balasənli, 2018). These universities have wider personnel and infrastructure when the material and technical basis and personnel of regional universities are weaker and they have fewer specializations.

Besides universities, two colleges providing tourism education (Baku Physical Education and Tourism College 
and Mingachevir Tourism College) are acting. Mingachevir Tourism College prepares various specialists and 4 of them are directly connected with tourism (Salihova et al., 2019). The majority of institutions providing tourism education in Azerbaijan started to act during the last 20 years and their alumni satisfy demands on tourism personnel only partly. In the Strategic Roadmap for Tourism Development, it was shown that only $10 \%$ of workers acting in the tourism sector are tourism specialists. The number of workers acting in the tourism sector in 2018 was 53222 people (ACC, 2020). When comparing Azerbaijan with countries having tourism relations with it (Turkey and Russia) we can observe that the number of tourism education schools and specialties provided, is much less than in those countries. 40 tourism faculties and 14 tourism management and hoteling institutions were acting in Turkey in 2018. Besides, there are 12 tourism management sections in the Economics and Organization of Business faculties of universities (Keles, 2018). The widening of the tourism education net caused an increase in the ratio of people working in the tourism sector. So 2000218 people were working in the tourism sector in Turkey in 2016 which was $8 \%$ of all working people (Şit, 2016).

It is planned for 2023 to increase the number of workplaces in the tourism sector by $80 \%$ in comparison with 2013 (Salihova et al., 2019). There is a tourism net in Turkey bringing together universities, vocational schools, and colleges and they play a significant role in the preparation of the personnel. The transformation of 200 vocational schools to colleges should be realized during the next 5 years (Bayramli \& Aliyev, 2020). Despite the big number of tourism education schools, many researchers are pointing out the existence of some serious problems in the tourism education field in Turkey. The main problems are shortages in the policy and planning of tourism education, weak coordination between the tourism sector and schools providing tourism education, deficiency of integration in tourism education, lack of legal protection of educated tourism specialists, an insufficient level of foreign languages (Olcay, 2008).

In Russia having close tourism relations with Azerbaijan, until 1990 there were not any higher education schools providing tourism education. 286 higher education schools providing tourism education have been registered in 2018 in Russia which made progress in the field of tourism education during independence. In Russia feeling deficiency in tourism personnel meeting international standards the main problem in tourism education is the provision of mainly theoretical knowledge to students and a low level of practical skills of alumni (Trusova \& Trusov, 2015). As a result of tourism reforms and some advancement in the field of tourism education, it became possible to raise the share of the tourism sector in the economy to $3.47 \%$ or 3 trillion rubles in 2017 (https://www.interfax.ru, 2018). 4.5\% of the able-bodied population worked in the tourism sector in Russia in 2017 and rising of this indicator to $5.9 \%$ is prognosticated in 2028. The researchers are pointing out that the absolute majority of people working in the tourism sector in Russia do not have professional tourism education. According to data of experts, about 80 percent of the present collaborators of domestic tourist firms do not have the relevant education (Radkov, 2019).

The existence of similar problems in the field of tourism both in Azerbaijan and in the selected comparison countries (Turkey and Russia) is being observed. In all three countries, the main problems are difficulties in the length of service and smallness of practical knowledge of alumni, insufficient level of foreign languages, weak coordination between the tourism sector and schools providing tourism education. The absence of a solution to tourism education problems is among the reasons why the rich tourism potential is weakly used in all three countries.

\section{Efforts for development of tourism education in Azerbaijan}

Holding of some international events (Eurovision 2012 -Song Contest, the First European Games, the Fourth Islamic Solidarity Games, Formula 1 Grand Prix, UEFA Europa League final, etc.) during the last 10 years not only raised the prestige of the country, but it also demonstrated how the preparation of tourism personnel is important. Declaration of tourism as one of the priority fields in the non-oil sector requires the development of tourism education. Tourism education is specially mentioned in the state programs of the country connected with tourism. One of the activity directions of the State Program on Development of Tourism in the Azerbaijan Republic in 2010-2014 adopted in 2010 was "Improvement of personnel preparation and refresher training system, the realization of projects on education abroad" (Hashimli, 2019).

"The Strategic Roadmap for Tourism Industry Development" can be evaluated as the most important stage in tourism education development. The fourth strategic goal of this document ratified on December 6, 2016, is the "creation of national tourism quality system for the increasing pleasure of tourists". The following measures for the development of tourism education were planned in "the Strategic Roadmap" (AzStat, 2016):

- Creation of a working group for coordination of tourism education and training programs;

- Creation of regional vocational schools of tourism within Azerbaijan University of Tourism and Management;

- Preparation of professional standards and curricula on the tourism sector and taking measures for 
certification of tourism guides;

- Organizing educational seminars for representatives of sectors connected with tourism;

- Taking measures for MBA programs on Tourism.

Strengthening professional tourism education is one of the main conditions for the complete realization of reforms conducted in this field. Despite this priority will not directly influence the sector, but will help increase the real GDP of Azerbaijan. Successful implementation of the Strategic Roadmap will be helpful for the creation of new working places in the education field and increasing the interest of young people in tourism specialization. Taking into consideration the development tendency of world tourism, features of tourism development in the country, development of new destinations and kinds of tourism, there is a need for preparation of "The Strategy of Tourism Education Development".

The creation of the State Tourism Agency in the country in 2018 can be evaluated as a continuation of structural reforms. Realization of the tasks of Agency (improvement of research and statistics for a longer development, preparation of relevant state programs and development concepts, marketing for defining the main tourism markets, taking propaganda measures for the involvement of tourists from suitable countries and regions, preparation and realization of marketing and communication plans of regions and cities, development of tourism education, the maximum use of opportunities of innovations and modern technologies in tourism, widening state-private business cooperation, etc.) is possible only by tourism education meeting the developed modern requirements (Salihova et al., 2019).

\section{Main peculiarities of tourism education in Azerbaijan}

The system of tourism education of Azerbaijan is similar to the system of developing and post-soviet countries. The peculiarities of tourism education in Azerbaijan belonging to the group of developing states because of the level of development can be generalized as follows:

- Tourism education is a new phenomenon for Azerbaijan. With small exceptions, tourism education started in the period ofindependence.

-Ecological and tourism consciousness is not inculcated before universityeducation.

- Tourism education schools are mainly concentrated in big cities and tourism education in the regions islimited.

- The number of specializations in universities providing tourism education issmall.

- The system of tourism education of Azerbaijan is similar to the system of post-sovietcountries.

- There is not any systematic approach in Azerbaijani tourismeducation.

- Frequent structural changes are observed in the schools providing tourismeducation.

\section{Problems of tourism education in Azerbaijan}

There has been no significant progress in the field of tourism education in Azerbaijan during the Soviet period which ended in 1991. Changes in tourism education in Azerbaijan became possible after the country gained independence in 1991. In the first years of independence, tourism departments were opened at various universities, and in 2006, the University of Tourism was established. Despite some work in the field of tourism education, only $10 \%$ of the country's tourism sector is qualified. The shortage of personnel in the tourism sector also hinders the sustainable development of tourism, making it difficult to fully utilize the tourism potential. At the same time, due to the shortage of professional staff, it is not possible to effectively carry out activities in the field of planning, marketing, and promotion in tourism.

Most of Azerbaijan's tourism education facilities are located in Baku. The number of tourism education establishments and specialties in the regions is low. Armenian occupation of $20 \%$ of Azerbaijani territory has made it impossible to establish tourism education facilities in the unique destinations of Nagorno-Karabakh and its surroundings. Lack of professional staff and quality textbooks in tourism education institutions in Azerbaijan has a negative impact on the development of tourism education. At the same time, there is a discrepancy between the curriculums in tourism education institutions. Inadequate understanding of tourism in higher education can be seen as an important disadvantage in tourism education.

In the Strategic Roadmap for Tourism Development, the numbers of graduates from tourism specialties are very low in Azerbaijan, despite the growing popularity of tourism among young people; it is not yet sufficiently 
prioritized by students because of its seasonal character. At the same time, it was noted that the material and technical base available in higher, secondary special, and primary vocational schools in Azerbaijan does not meet international standards, and students are being taught more theoretical knowledge. All these factors make it necessary to hold reforms in tourism education and to study the experience of advanced tourism countries, and to take into account the social and economic conditions in Azerbaijan.

\section{SWOT analysis on tourism education in Azerbaijan}

Analysis of tourismeducation in Azerbaijan has allowed summarizingits strengths and weaknesses, as well as opportunities and threats. The results of the author's SWOT analysis are givenbelow (see table 1).

Table 1. SWOT analysis of tourism education in Azerbaijan

\begin{tabular}{|c|c|}
\hline Advantages & Weaknesses \\
\hline $\begin{array}{l}\text { 1. Availability of tourism education university, tourism } \\
\text { departments at several universities and colleges } \\
\text { 2. Certain experience in tourism education } \\
\text { 3. Availability of a certain number of personnel studying } \\
\text { abroad in the field of tourism } \\
\text { 4. To highlight the need to improve the quality of tourism } \\
\text { education and conduct tourism research in government } \\
\text { tourism programs. } \\
\text { 5. Providing certain internship opportunities for students } \\
\text { studying tourism } \\
\text { 6. Availability of masters and doctoral education in some } \\
\text { universities of the country in the field of tourism education }\end{array}$ & $\begin{array}{l}\text { 1. Lack of understanding of tourism in lyceums and } \\
\text { secondary schools } \\
\text { 2. Fewer universities and colleges providing tourism } \\
\text { education } \\
\text { 3. The fact that tourism education facilities are mainly } \\
\text { located in the capital Baku and there are few tourism } \\
\text { education facilities in the regions. } \\
\text { 4. Lack of specialties in tourism education institutions } \\
\text { 5. Lack of highly qualified tourism personnel in universities } \\
\text { 6. Lack of quality textbooks } \\
\text { 7. Limited opportunities for students studying in tourism to } \\
\text { study abroad } \\
\text { 8. Poor cooperation between tourism companies and } \\
\text { universities. }\end{array}$ \\
\hline Opportunities & Threats \\
\hline $\begin{array}{l}\text { 1. Transformation of Azerbaijani high schools with great } \\
\text { potential (UNEC, Baku State University and Khazar } \\
\text { University) into tourism education centers of the region } \\
\text { 2.Sending Azerbaijani tourism graduates to gain masters and } \\
\text { doctoral education to Turkish universities where language } \\
\text { problems are not experienced. } \\
\text { 3. Organization of teacher and student exchanges with } \\
\text { Tourism Universities in Turkey, Russia, Ukraine, } \\
\text { Kazakhstan. } \\
\text { 4. To provide internship in prestigious scientific centers of } \\
\text { the world cooperating with Azerbaijani universities. } \\
\text { 5. Creation of a personnel bank for the tourism sector. } \\
\text { Increasing the tourism quota in the list of students sent } \\
\text { abroad through the Ministry of Education of Azerbaijan. } \\
\text { 6. Active participation in the educational projects of the } \\
\text { World Tourism Organization, UNESCO and other } \\
\text { international organizations. } \\
\text { 7. Use the North-South and East-West transport corridors to } \\
\text { expand tourism links }\end{array}$ & $\begin{array}{l}\text { 1. Occupation of tourism areas of Azerbaijan, such as } \\
\text { Shusha, Khankendi and Kalbajar and failure to establish } \\
\text { tourism education facilities } \\
\text { 2. The problem of finding employment for graduates of } \\
\text { tourism department } \\
\text { 3. Redirecting recipients of tourism education to other areas } \\
\text { 4. The influx of graduates from tourism departments to } \\
\text { foreign countries } \\
\text { 5. Non coming back students studying tourism abroad }\end{array}$ \\
\hline
\end{tabular}

\section{Results, Conclusions and Recommendations}

The rapid development of tourism in Azerbaijan requires improvement of tourism education. In order to solve the problems related to tourism education in the country, we consider it expedient to implement the following measures.

- Inclusion of tourism-related sections to the books "Geography and Life Knowledge" taught in high school in order to increase the understanding of tourism (consciousness) at an early age;

- $\quad$ Organization of Tourism Olympiads in the country;

- Organization of Young Tourists Clubs in secondary schools and colleges;

- Strengthening the material and technical base of universities and colleges providing tourism education;

- Establishing network of vocational schools providing tourism education;

- Sending employees in tourism education institutions to the leading tourism education universities of the 
world for research and internship purposes and to tourism companies providing internship opportunities. leaders in the world's leading tourism education universities and internship tourism companies;

- Implementation of "Tourism-oriented Secondary School $\rightarrow$ Vocational Schools $\rightarrow$ Colleges $\rightarrow$ University" scheme in the tourism education system;

- Creation of jobs in the tourism sector for women and youth;

- Resolving the insurance problem of the tourism sector;

- Definition of professional standards in tourism;

- Establishment of cooperation between the tourism sector and tourism education institutions;

- Implementation of effective planning of tourism education;

- Development of joint internship programs by tourism companies and companies;

- Strengthening foreign language teaching in tourism education institutions;

- Opening of tourism guide courses by professional teachers;

- The use of Turkey's Anatolian Tourism Specialist internships.

Azerbaijan needs to expand its rapidly developing tourism sector and increase investment in this area. The provision of the tourism sector with qualified personnel depends on the quality of education. For the comprehensive development of tourism education in Azerbaijan, it is necessary to develop and implement the "Tourism Education Strategy" based on the priorities outlined in the Strategic Roadmap.

The three-tiered tourism education system could be more useful for Azerbaijan. If this system is implemented, it will be possible for the tourism sector to train all personnel from technical staff to managers. Qualitative tourism education is of particular importance in terms of optimizing the environmental impact of tourism and sustainable development of tourism. Effective use of Azerbaijan's rich tourism potential will depend on the development of tourism education in the country.

\section{References}

1. ACC. (10 Ekim 2020). Azərbaycan İqlimi. Azərbaycan Coğrafiya Cəmiyyəti: http://www.gsaz.az/articles/view/91/Azarbaycanin-iqlimi, Erişim tarihi: 10 Ekim 2020.

2. AzStat. (2016). Strategic Roadmap for the Development of Tourism Industry in the Republic of Azerbaijan, Baku.

3. Balasənli, K. (2018). Azarbaycanda Alternativ Turizm Növlarinin Inkişaf Problemlari. Bakı: UNEC.

4. Bayramli, G., \& Aliyev, V. (2020). Econometric Analysis of Tourist Demand in the Absheron Peninsula (Baku-Azerbaijan). Research in World Economy, 11(3), 251-260.

5. Oliyeva, İ.N. (2008). Azarbaycan Respublikasında Turizmin İnkişafinın Perespektivlari va Regional Problemlar.Bakı: Az.Res.Təh.Naz.

6. Fedulin, A.A. (2008). Tourism problems: new horizons of development, Problems of Service and Tourism, 1(71), 72-76.

7. Hashimli, M. (August 01, 2019). Azerbaijan's Tourism Sector - Opportunities and Obstacles. Available at SSRN: https://ssrn.com/abstract=3485581 or http://dx.doi.org/10.2139/ssrn.3485581

8. Keles, Y. (2018). Why Tourism Education? A Research on Undergraduate Tourism Students, Journal of Tourism and Gastronomy Studies, 6 (4), 220, 219-236.

9. Olcay, A. (2008), Importance of Education in Turkish Tourism, Gaziantep University Social Science Journal, 7(2), 383-390

10. Mavis, F., \& Kozak S. (1992). Tourism Program at Specialty Schools and Anatolian University, (Eskişehir Specialized School) Program on Department of Tourism and Hotel Management, 169, 169172 .

11. Radkov, A. (2019). Kadrovaya situatsiya daleka ot optimalnoy. Polucheno 11022021 g., iz Akkreditatsiya v obrazovanii: https://akvobr.ru/radkov_kadry_dla_turizma.html

12. Salihova, S., Bayramli, K., \& Aliyeva, B. (2019). The Impact between Tourism Sector, GDP and Export: Statistical Analysis Approach the Example of Kazakhstan. International Journal of Civil Engineering and Technology, 10(05), 996-1002.

13. Şit, M. (2016), Employment Contribution of Tourism Sector in Turkey, Journal of Academic Approaches, 7(1), 101-117.

14. Trusova, N. M, \& Trusov, A. N, (2015). Visioning in the Sphere of Tourism: The Problems and Roots of the Renaissance, Vestnik KemGUKI, No. 33., 177-186, Available online: http://tourlib.net/statti_tourism/trusova.htm. (accessed on 18/01/2021). 